\title{
The Value of Santri in Political Moments: an Identity
}

\author{
Min Hajul Abidin*, Yang Dong \\ Department of Psychology, Southwest University, China \\ *Corresponding Author: minha.abid@gmail.com, yangd@swu.edu.cn
}

\begin{abstract}
Nahdlatul Ulama (NU) is one of the largest religious organizations in Indonesia. The santri community that is very identical to $\mathrm{NU}$ has contributed to Indonesia's development. When viewed from history, Santri were actively involved in Indonesian politics. The contribution of the santri is seen in various strategic positions of the country. The purpose of this study was to determine the attitude of the santri identity in political moments. This study uses a case study method to determine the process and central dynamics of santri in political activity. Semistructured interviews were used to determine the identity construction of two subjects who had different backgrounds, but both were NU members who were raised in the santri tradition. The results showed that the santris' attitude did not have a particular patron/command and was amoeba/spread in various positions. Santri builds a unique identity as pride and has more value than other groups. Another result shows that political activity is considered an activity in worship.
\end{abstract}

Keywords: Nahdlatul Ulama, Santri, Identity, Unique, Politics.

\section{Introduction}

Indonesia is a country with the largest Muslim population in the world. The total population is 214,375,487 (88.2\%) Muslim population in 2010 and is expected to increase to 240,011,944 Muslim population by 2020 (Kettani, 2010). Santri is one of the informal religious groups in Indonesia. In general, the santri groups study and embrace the thoughts of Ahlussunah Waljama'ah, which identifies Nahdlotul Ulama (NU), the largest Muslim organization in Indonesia (Niam, 2017). They have their uniqueness that is different from other groups; Abdurrahman Wahid called it a Subculture (Wahid \& Rahardjo, 1988).

Santri entered into political activity in Indonesia can be identified since the Mataram Islam kingdom's time, and it has become increasingly apparent during the Dutch and Japanese colonial times, at the beginning of independence until now. In general, the history of Santri is preceded by the history of Islam's spread by the 
Walisongo in Indonesia. The Islamic teachings spread by the Walisongo have a unique characteristic, namely the spread of early Islam adapted to the community's circumstances. This can be seen when Walisongo spread Islamic teachings. The local community's culture is often used as the primary capital for them to insert Islamic teachings. For example, Sunan Kalijaga uses puppets as a medium of preaching. The Islamization of culture as a strategy for spreading Islam certainly greatly facilitates accepting the teachings conveyed. Walisongo succeeded in spreading and developing Islamic teachings in Indonesia (Mahdi, 2013).

Mahdi (2013) added that in the Walisongo era, the term Pondok Pesantren became known in Indonesia. At that time, Sunan Ampel established a hermitage in Ampel Surabaya as a center of Java center. The santri who came from the island of Java came to study religion. Some of the Santri even came from Gowa and Talo, Sulawesi. This Sunan Ampel hermitage is considered to be the forerunner to the establishment of pesantren throughout Indonesia. The behavior of the Santri, in general, follows the direction of the leader or can be said to have a high dependence on the leader, namely the Kiai (Azro'i and Fuaidi 2020).

The next period was the Dutch colonial period in Indonesia. During this colonial period, pesantren always faced Dutch colonialists who severely limited their space. The Dutch government issued a political education policy in the Wild School Ordinance or Wide School Ordinance form. Through this policy, the Dutch wanted to kill madrasah (Islamic School) and schools that did not have a permit. In addition, this formal Dutch policy also aims to prohibit the teaching of Islamic books that they think can create subversion or resistance movements among santri and Muslims in general. At least four times, the Dutch issued regulations aimed at shackling the development of Islamic boarding schools in Indonesia, namely in 1882, 1905, 1925, and 1932 (Mahdi, 2013).

Santri' participation in matters relating to the nation and state began to be clear and focused after forming an organization calling itself Nahdlatul Ulama (Syaiful, 2005). This activity impacted santri, who began to be involved in many political activities. Santri has a long process in politics (Yusuf et al., 1983). Even Indonesia's 4th President Abdurrahman Wahid has a santri background, and the 13th vice president of Indonesia also has a strong NU background. 
The inclusion of the santri in political activities makes the santri have a new social identity, not as theologians but as practical politicians. Political elites are a small group of people who significantly influence making and implementing political decisions (Haryanto \& Rahmania, 2015). In this condition, the involvement of the santri changes in social identity. Social identity is "part of an individual's selfconcept that comes from knowledge of his membership in a social group (group), along with its values and emotional meanings." There are three theoretical principles of social identity. First, Group members strive to achieve or maintain a positive sense of social identity. Second, group members' social identity underlies this comparison on the good things that can be done between the relevant in-group and out-group members. Social categories or groups, of which individuals are members, give individuals a social identity, enabling them to compare their group with relevant external groups. These comparisons contribute to individual selfesteem because they allow individuals to determine and create a difference that their group members are better at than other groups. Third, group members will try to leave their group or join other, more positive groups when their social identity does not satisfy them (Cottam et al., 2012).

Social identity is described as attractiveness, care, the pride that is derived from one's knowledge of various categories of social membership with other members, even without the need to have close personal relationships, know or have various interests (Huda, 2012). Apart from Hogg's (2002) Social Identity Theory, three factors influence the formation of social identities, namely (a) selfcategorization, (b) social comparison, and (c) interactional models (Putri, 2013).

In conclusion, social identity theory is a sense of attachment, belonging, caring, and pride as a member of a group, and in various categories of social membership with other members, even without having a special close relationship with each other, this understanding emerges from knowledge as members certain social groups.

Santri, who is represented by various members as politicians, also contributes to Indonesia's significant political dynamics. The activities of santri in politics have been recognized in Indonesia, as evidenced by the Hari Santri Nasional (HSN) holding every October 22, the Liga Santri Nusantara (LSN) several activities carried 
out by the president, ministers, or state officials related to santri. So what are the dynamics of santri identity in political activities? Moreover, what is the goals of the Santri when they enter into political activities?

The method used in this research is a case study. This method was chosen because it is one of the superior methods in bringing about an understanding of complex problems and can add strength to what has been known through previous research plus, it emphasizes a detailed contextual analysis of several events or conditions. and their relationship (Dooley, 2002). Case studies are also a research strategy that focuses on understanding the dynamics that exist in a single setting (Eisenhardt, 1989). In this case, it will focus on the dynamics of Santri.

This research was conducted in different areas, namely in Klaten and Yogyakarta Regencies in 2017. Subjects were two people consisting of the head of the DPC PKB Kab. Klaten is also the chairman of the PKB Faction at the Klaten Regency DPRD and a Yogyakarta Provincial KPU. The technique used was semistructured interviews, with supporting data by the Klaten PKB Syuro Council and Yogyakarta Provincial KPU assistants. The two subjects were chosen because the two subjects had the characteristics needed in the study. Some of these characteristics included being Santri, especially in values, and being active in political activities or moments.

\section{Santri Identity in political Moment}

Researchers conducted interview data several times to both subjects directly and interviews with people close to the subject (significant other). The results of the interview were processed by codifying and reducing. In general, the dynamics of the santri identity of the two subjects are obtained from several stages:

\section{A. Family process}

The family stage is the earliest stage for the two subjects to get internalization of values as Santri. The family background of the two subjects is a family that upholds the values of Santri. Both subjects, since their childhood, were educated and raised with santri values. As experienced by Subject 1 comes from a family with a santri background, where both parents have the NU ideology (the subject emphasizes this). This data is strengthened by data 
obtained from several other significant statements that the wife of subject 1 comes from a family with a pesantren. "... an arranged marriage with a wife, still with a pesantren family, and a strong NU (ideological) background" (so-2 / w-1 / 146-150).

Furthermore, the subject one is known to have started a career as an active person in the santri organization (NU). According to the admission of subject 1 , he had served in several organizations related to Santri activities, namely the Pedan District NU Management, Klaten Regency NU Branch Manager, the Chairperson of the Partai Kebangkitan Bangsa (PKB), and as Chair of the National Awakening Party Faction in Klaten Regency.

Unlike subject 1 , active in political parties, subject 2 has activities as a General Election Commission. The background of subject 2 is a child from a family who applies santri values. Subject 2's family has a strong santri (NU) background, both from its father and mother. The subject's father studied Islam in Islamic boarding schools in several places, such as in Jombang Regency and Rembang Regency. His mother had a background in Islamic boarding schools in Jombang Regency. He felt that he was a santri who studied religion and had attended a pesantren, which gave him the values of being a santri.

"Their activities (my parents), (how to educate) the references they built were inherent in my tradition of behavioral knowledge from my childhood, so when I was a child, I was introduced to religious knowledge (with the NU tradition)" (w-2 / s-2 / 152-155)

\section{B. Educational Process}

The search for identity as santri in both of them is through the idea of a moratorium. The psychosocial stage between childhood and adulthood, and between the morality learned by children and the ethics that adults will develop. These are ideological thoughts and ideological expectations about the society that speaks as vividly as to the youth whom their peers want to affirm and readily confirm by various rituals, statements of belief, and programs while defining what is evil, strange, and contradictory (Erikson, 2010).

This process is strongly supported by the education of both subjects, both formal and informal education. Subject 1, while being a Santri at a university in 
Semarang city, lived in an Islamic boarding school. Here, subject 1 strengthens the Santri' previously obtained values . In addition, subject 1 is also active in organizational activities that support Santri' internalization.

Lesson 2 had a different experience when he was in junior high school (SMP) continuing his education at the pesantren. At the next level, namely, at the Senior High School level (SMA), subject 2 continues his education in the Islamic boarding school. In this process subject, 2 received more scores as a Santri than before; one of them is when subject two can be familiar and have friends from various ethnic backgrounds without distinguishing their origin or ethnicity.

"Santri, in our sense, are people who follow what his name is, taking part includes learning, including what is called following the actions of a Kiai, santri, Santri are said to be Santri in general, santri is in the sense of learning from Kiai, no. All Santri are said to be santri, but here when we talk about Santri, we must refer to the Kiai "(s-1 / w-2 / 211-219).

\section{The Process of Santri Identity in Politics}

Both subjects have a background in the family, education, and organization of the Santri. Subject 1 had once served as a board member of the boarding school at Al Munawir Islamic Boarding School Semarang, plus subject one was also included in the PMII organization. The wife of subject 1 is also a Dzurriyah PP Al Munawir Semarang. Gait in subject one organization, namely in NU from sub-district to district level, and PKB.

Subject 2 has a strong santri background; subject 1's father and mother are genuine Santri. The family tradition taught in subject 2 is always the santri tradition. The education pursued by subject two is always related to the pesantren, from the elementary school educated by his father and the junior and senior high school levels in the pesantren. At the time of entering college, subject 2 followed the PMII organization, which he had a relationship with Santri.

The search for identity as santri in both of them is through the idea of a moratorium. The psychosocial stage between childhood and adulthood, and between the morality learned by children and the ethics that adults will develop. These are ideological thoughts and ideological expectations about the society that speaks as vividly as to the youth whom their peers want to affirm and readily confirm by various rituals, statements of belief, and programs while 
defining what is evil, strange, and contradictory (Erikson, 2010). Both have the ideology of NU Santri. The crisis between the two subjects in their identity occurred when they joined an organization related to Santri and understood themselves to carry out positive evaluations.

The next process that happened to the two subjects was that they believed that they were part of the santri group; both of them were very proud to be part of the santri group. Both of them also have the initiative to raise the santri group with their respective strategies.

The conditions experienced by the two subjects can be explained in the chart below:

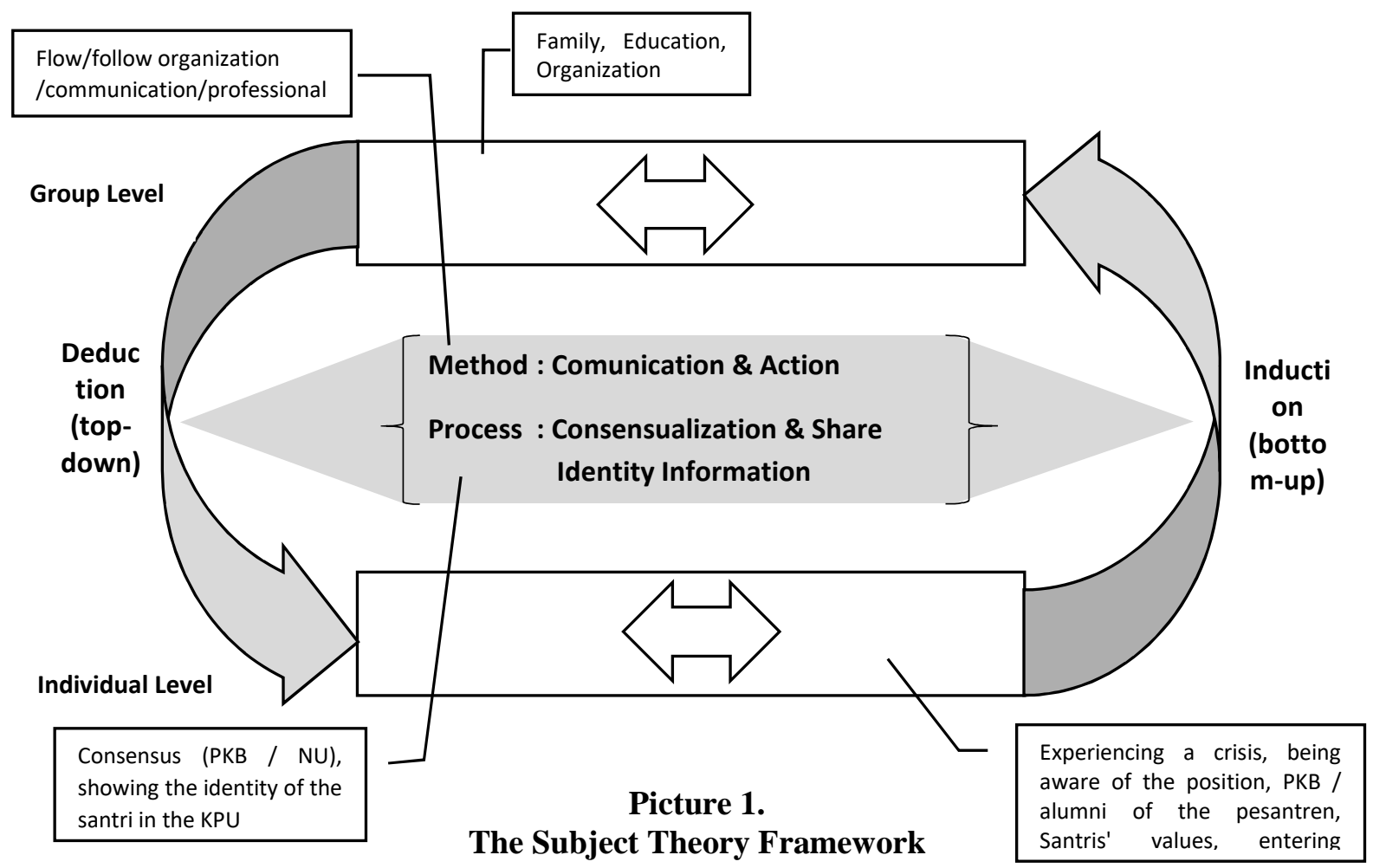

The description of the data above can specifically be:

The picture above shows the process by which both group and individual factors form an individual social identity, two models that can explain this process, namely through the process of induction (bottom-up) and deduction (top-down). The induction model describes the process of forming a social identity from an individual's point of view. This process can be understood when individuals have realized the importance of their social relations with group members, with shared consensus. The second model is the deduction (top- 
down). This model emphasizes the function of groups as individual social identities. That the group has and practices specific attributes and values that exist in the group that binds its members to become a collective unit (Afif, 2012).

It can be concluded that the two models of social identity formation cannot be separated from one another. This process is complimentary. When examined further, the two have formed a circular chain that is difficult to identify, which is the beginning and the end (Afif, 2015). The two subjects were indeed raised with the Nahdlyyin tradition, but this would not affect if they did not know their respective roles as santri in politics. The formation of this awareness goes through a long process of life in the two subjects.

Brewer's (1979) theory of social identity develops further from the theory of discrimination. According to Abrams et al. (1990) social identity theory, individuals require an order in the social environment. As a result, individuals place themselves around them in social categories, which define them as membership of a group. However, a group can only exist if it is defined in terms specific to another group and can only maintain its identity if the group maintains a meaningful existence from other groups. This, according to Turner (1982), is related to the sharp difference in the relationship between groups which leads to bias within groups and groups outside, where groups tend to sharpen the differences between them in forming positive uniqueness, while bias in groups affects The perception of the relationship between groups and the interaction of several relationships seems to be a factor that strengthens this condition (Huda, 2012).

Social identity theory is defined as an individual's knowledge that he belongs to a specific social group and some of the emotions and values that are significant to him from membership in this group. Whether large demographic categories or small task-oriented teams, social groups give their members a shared identity that defines and evaluates who they are, what they should believe, and how they should behave. Social identity is also very critical, highlighting how inner groups differ from out-groups relevant in specific social contexts (Hogg, 2016). Furthermore, social identity is reflexive because it can 
make itself an object and categorize, classify, and name itself in specific ways about other social categories or classifications (Stets \& Burke, 2000).

Both subjects felt like part of the Santri social group, where both subjects had the same social identity - they identified themselves in the same way and had the same definition of who they were, their attributes, and how they were related and different from certain outside groups (Santri). Group membership is a matter of collective self-constructiveness - "us," "us," and "them." Social identity is very different from personal identity. Personal identity is selfconstrual in terms of idiosyncratic personality attributes that are not shared with other people ("I") or a close personal relationship that is entirely tied to a specific another person in the sister ("I") and you ") relationship. has to do with group processes. However, group life may provide a context in which personal identities are formed, for example, friendship and hostility (Hogg et al., 2004).

The theory above is in accordance with what was experienced by the two subjects. Subject 1 felt that other parties always took advantage of the santri group at certain moments and did not consistently fight for the santri; according to him, this had happened a long time ago. Subject 2 felt that Suharto was a figure of an authoritarian regime with Abrinya. Both subjects experience discrimination as santri in politics. Both subjects show part of the santri group, where each person has as much social and personal identity as the group they feel is part of or the personal relationship they have. Identities vary in subjective importance and value, and chronic and situational accessibility (Hogg et al., 2004).

Both of them position themselves as Santri who occupy strategic positions. Both of them assumed that their position, both subject one as DPRD and subject two as KPU Commissioner, had more value than their other colleagues who were not Santri. This behavior shows that the subject experiences social categorization, or what Turner et al. (1987) call it the social identity process's cognitive heart.

People cognitively represent groups in terms of prototypes of interrelated attributes that simultaneously capture structural similarities and relationships within groups and differences between groups and determine group 
membership's associated behavior. Prototypes are constructed sociallycognitively according to the metacontrast principle (maximizing the ratio of perceived intergroup differences to intragroup differences) to accentuate entitativity (the degree to which categories appear to be distinct and structured entities), balanced with a concern for representing groups profitably. Thus, the prototype seldom describes an average or typical group member; on the contrary, they have polarized away from extraneous characteristics and represented the ideal, often hypothetical, group members. Prototypes cannot be formed or maintained purely by their intragroup comparisons depending on the comparison between groups. Thus, the intragroup process cannot be separated from the broader context between groups (Hogg et al., 2004).

Both also conducted positive evaluations regarding the current position of the Santri. Subject 1 was of the view that Santri, apart from mastering the klasik books, must also master technology. According to subject 1 , it is compulsory with PKB because PKB has always fought for the santri. Subject 2 believes that it is time for Santri to fill strategic state posts, not only be concentrated in one area. The subject views that if these strategic posts are not controlled by good people (santri), it will be dangerous.

When intersecting with other groups in politics, the two subjects put forward values that are considered to be characteristics of the santri. Subject 1 took the attitude of raising NU with the PKB path as a way of worship, which always asked the Kiai's opinion as a reference. Subject 2 applies the values of Santri at the level of KPU commissioners with Fiqh reasoning. Subject 2 positioned himself as Khodamul Ummah.

This study's results support other research, namely social identity, is formed from the same background (Rahmawati, 2018). Research conducted by Rahmawati (2018) shows that apartment residents are formed influenced by the pluralistic background of residents who live in the same location. The similarity of identity as part of the group will bring out the social identity that is owned between members.

Another finding that has a similar result is the interaction process experienced by the two subjects to build an identity as a santri. Social contact is 
a medium for communication as a process to build a social identity in a group, a finding supported by Hamzah et al. (2019). Social contacts requiring group equality, cooperation, common goals, and support from authorities can be manifested in organizations such as graduate Santri organizations.

The family factor is an essential aspect in shaping one's identity. Islam has mentioned the importance of family in shaping one's identity. Family, which is the first and foremost educational institution (Usman, 2017). In the Al-Quran letter At Tahrim 6 (QS 66: 6) which means more or less are:

"O you who believe, protect yourselves and your families from the fires of hell, whose fuel is men and stones; the guardians of angels who are harsh, harsh, and obey Allah against what He commands them and always do what is ordered" At Tahrim 6 (QS 66: 6)

\section{Conclusion}

Based on the findings through interview and observation methods and data processing in this study, the two subjects' social identity processes are not the same, but in general, the two subjects have the same goal, namely to raise the group they are proud of, namely the santri group. The formation of identity politics in the two subjects occurred because things were not much different, namely disappointment or discrimination. Subject 1 felt disappointed because NU's position was always cheated by other groups, even since NU was part of the PPP ranks, which entered the New Order era lead by Soeharto. The subject feels that PKB is the only one that always fights for NU because PKB has a close history with NU, or even the subject says that PKB was founded by NU to become a political tool for NU citizens. The disappointment of subject 2 is almost the same as subject 1, where subject two was educated during the authoritarian Suharto era with ABRI at that time. The subject's disappointment with Soeharto's political system was accommodated in the organization he joined, namely PMII. In this organization, he discussed NU's position or Santri with the state and the position of Santri with the state.

The two subjects have different backgrounds; both form different identities in society, namely as PKB and KPU. The meaning that they have as a form of identity is different. Subject 1 identifies himself in politics as part of the PKB, which always 
fights for NU. Subject 2 identified himself as Khodamul Ummah with the values of the Santri through the KPU. The existence of both of them is the identity of being a santri in political activities, which is very encouraging because Santri have unique characteristics that distinguish themselves from others in political activities. Further research is expected to be able to increase the number of subjects that will expand the data obtained. Further research is also expected to present a female figure who is the subject of research because the position of Santri who become political elites is not only men such as Khofifah Indar Parawangsa, Yeni Wahid, and so on. Further research should also add more varied subjects, for example, Santri who belong to the nationalist party or parties other than PKB, such as PDIP, Democrat, Golkar, and even PKS, because it will produce varied and more interesting data, of course.

\section{References}

Afif, A. (2012). Identitas Tionghoa Muslim Indonesia: Pergulatan Mencari Jati Diri. Penerbit Kepik.

Afif, A. (2015). Teori identitas Sosial. Yogyakarta: UII Press.

Azro'i, I., Fuaidi, I. (2020). The Existence of Pesantren: Implication Study of Pesantren Leadership Regeneration in Central Java. Santri: Journal of Pesantren and Fiqh Sosial 1(1): 1-12.

Cottam, M. L., Beth, D.-U., Elena, M., \& Thomas, P. (2012). Pengantar psikologi politik. Edisi Kedua. Jakarta: Raja Wali Pers.

Dooley, L. M. (2002). Case study research and theory building. Advances in Developing Human Resources, 4(3), 335-354.

Eisenhardt, K. M. (1989). Building theories from case study research. Academy of Management Review, 14(4), 532-550.

Hamzah, I. F., Agoha, C., \& Silviani, A. (2019). Membangun Identitas Sosial dalam Organisasi Mahasiswa Pascasarjana. Psycho Idea, 17(1), 32-41.

Haryanto, H. C., \& Rahmania, T. (2015). Bagaimanakah Persepsi Keterpercayaan Masyarakat terhadap Elit Politik? Jurnal Psikologi, 42(3), 243-258.

Hogg, M. A. (2016). Social identity theory. In Understanding peace and conflict through social identity theory (pp. 3-17). Springer.

Hogg, M. A., Abrams, D., Otten, S., \& Hinkle, S. (2004). The social identity perspective: Intergroup relations, self-conception, and small groups. Small Group Research, 35(3), 246-276. 
Huda, M. J. N. (2012). Teori psikologi sosial makro. Ash-Shaff.

Kettani, H. (2010). Muslim population in Asia: 1950-2020. International Journal of Environmental Science and Development, 1(2), 143.

Mahdi, A. (2013). Sejarah Dan Peran Pesantren Dalam Pendidikan Di Indonesia. Islamic Review: Jurnal Riset Dan Kajian Keislaman, 2(1), 1-20.

Niam, K. (2017). Nahdlatul ulama and the production of muslim intellectuals in the beginning of 21st century indonesia. Journal of Indonesian Islam, 11(2).

Putri, K. R. A. (2013). Hubungan Antara Identitas Sosial dan Konformitas dengan Perilaku Agresi pada Su-porter Sepakbola Persisam Putra Samarinda. Psikoborneo, 1(3).

Rahmawati, I. (2018). Identitas Sosial Warga Huni Rusunawa. MEDIAPSI, 4(2), 7682.

Stets, J. E., \& Burke, P. J. (2000). Identity theory and social identity theory. Social Psychology Quarterly, 224-237.

Syaiful, M. (2005). Politik Kiai dan Implikasinya Terhadap Politik Santri (Studi Kasus Pondok di Kaliwungu Kendal). Semarang: UIN Walisongo.

Turner, J. C., Hogg, M. A., Oakes, P. J., Reicher, S. D., \& Wetherell, M. S. (1987). Rediscovering the social group: A self-categorization theory. Basil Blackwell.

Wahid, A., \& Rahardjo, M. D. (1988). Pesantren dan pembaharuan. Lembaga Penelitian, Pendidikan dan Penerangan Ekonomi dan Sosial.

Yusuf, S. E., Syam, M. I., \& Masudi, M. F. (1983). Dinamika kaum santri: menelusuri jejak \& pergolakan internal NU. Rajawali. 
The Value of Santri in Political Moments ... 